\title{
UPAYA MENINGKATKAN HASIL BELAJAR MATEMATIKA DENGAN PEMBELAJARAN THINK TALK WRITE BERBANTUAN MEDIA GAMBAR PADA SISWA KELAS VI SD NEGERI 1 PURWOSARI
}

\author{
Samsi \\ SD Negeri 1 Purwosari \\ Email: samsisaba@yahoo.com
}

\begin{abstract}
The aims of this research were to increase the mathematics result of study by implementation of Think Talk Write (TTW) learning with picture media. The method of the research was Classroom Action Reserach. The instrument of data collection used test. Technique of data analysis used qualitative and quantitative analysis. The research result showed mean the result of study in cycle I is 56,30 and cycle II is 76,10. Then Think Talk Write (TTW) learning with picture media can increase the mathematics result study.
\end{abstract}

Keyword : mathematics result study, picture media, think talk write

\section{PENDAHULUAN}

Salah satu sektor penting dalam pembangunan suatu negara adalah melalui pendidikan. Menurut Undang-Undang No. 20 Tahun 2003 pendidikan merupakan usaha sadar dan terencana untuk mengembangkan segala potensi yang dimiliki siswa melalui proses pembelajaran. Pendidikan bertujuan untuk mengembangkan potensi anak agar memiliki kekuatan spiritual keagamaan, pengendalian diri, berkepribadian, memiliki kecerdasan, berakhlak mulia, serta memiliki keterampilan yang diperlukan sebagai anggota masyarakat dan warga negara. Untuk mencapai tujuan pendidikan yang mulia ini disusunlah kurikulum yang merupakan seperangkat rencana dan pengaturan mengenai tujuan, isi, dan bahan dan metode pembelajaran.

Pentingnya pendidikan juga dikemukakan oleh Sanjaya (2006) bahwa proses pendidikan berujung kepada pembentukan sikap, pengembangan kecerdasan atau intelektual, serta pengembangan keterampilan anak sesuai dengan kebutuhan. Pendidikan dapat diperoleh seseorang diberbagai tempat, salah satunya adalah melalui pendidikan formal. Pendidikan formal merupakan jalur pendidikan yang terstruktur dan berjenjang yang terdiri atas pendidikan dasar, pendidikan menengah, dan pendidikan tinggi (UU No. 20 Tahun 2003).

Pada pendidikan formal, tempat pelaksanaan proses pendidikan tersebut biasanya 
disebut dengan sekolah. Dalam sekolah, setiap siswa memperoleh berbagai mata pelajaran yang telah disesuaikan dengan tujuan pendidikan yang telah disusun. Salah satu mata pelajaran yang selalu diberikan, baik dari pendidikan dasar, pendidikan menengah maupun pendidikan tinggi adalah matematika. Artinya, mata pelajaran matematika ini memang sangat penting dikuasai oleh siswa karena banyak digunakan pada kehidupan seharihari. Lebih lanjut, Rochmad (2013) menjelaskan bahwa pada mata pelajaran matematika banyak materi yang dapat mengantarkan siswa memiliki keterampilan berpikir kritis dan kreatif.

Namun pada kenyataannya masih banyak siswa yang menganggap matematika adalah pelajaran yang sulit sehingga banyak siswa yang tidak begitu suka dengan matematika. Hal ini juga dirasakan pada siswa kelas VI SD Negeri 1 Purwosari Kecamatan Natar. Siswa kelas VI SD Negeri 1 Purwosari merasakan bahwa matematika adalah mata pelajaran yang cukup sulit dan siswa kebanyakan lebih menyukai mata pelajaran selain matematika. Hal ini juga ditunjukkan oleh hasil belajar siswa kelas VI pada mata pelajaran matematika. Berdasarkan hasil belajar yang diperoleh siswa, diketahui bahwa masih banyak siswa yang belum memperoleh nilai yang baik yang dapat diketahui dari nilai sebagian besar siswa yang belum mencapai ketuntasan. Untuk itu perlu adanya pembelajaran agar siswa mendapatkan suatu kemudahan dan merasa senang dalam belajar matematika. Sehingga dapat meningkatkan hasil belajar matematika.

Diantara berbagai jenis pembelajaran yang ada, salah satu pembelajaran yang perlu dipertimbangakan adalah pembelajaran Think Talk Write (TTW). Pembelajaran TTW adalah salah satu pembelajaran berkelompok yang mudah diterapkan dan dapat melibatkan aktivitas seluruh siswa. Pada dasarnya pembelajaran TTW melibatkan tiga tahap yaitu berpikir (think), berbicara (talk), dan menulis (write). Menurut Yamin dan Ansari (2012) pembelajaran TTW dapat dilakukan dengan cara berikut.

1) Guru membagi LKS yang memuat situasi masalah dan petunjuk serta prosedur pelaksanaannya.

2) Siswa membaca teks dan membuat catatan dari hasil bacaan secara individual, untuk dibawa ke forum diskusi (think).

3) Siswa berinteraksi dan berkolaborasi dengan teman untuk membahas isi catatan (talk). Guru berperan sebagai mediator lingkungan belajar.

4) Siswa mengkonstruksi sendiri pengetahuan sebagai hasil kolaborasi (write). 
Pada pembelajaran TTW, setiap siswa akan berpikir terlebih dahulu dan mempunyai pendapat sendiri dalam menyelesaikan tugas mandiri. Jadi sebelum siswa masuk ke dalam kelompok belajar, siswa sudah mempunyai pendapat tentang materi yang dipelajari, sehingga mereka akan saling bekerja sama dan saling membantu dalam memahami materi dan menyelesaikan tugas.

Selain dari sisi model pembelajaran yang digunakan, pemanfaatan media dalam proses pembelajaran dirasa juga cukup membantu siswa dalam memahami suatu materi yang dipelajari. Menurut Sundayana (2013), media dapat diposisikan sebagai suatu alat atau sejenisnya yang dapat dipergunakan sebagai pembawa pesan dalam suatu kegiatan pembelajaran. Dengan menggunakan media, konsep dan simbol matematika yang tadinya bersifat abstrak menjadi konkret.

Salah satu media yang cukup mudah digunakan adalah dengan media gambar. Media gambar merupakan bagian dari media visual yang merupakan media yang hanya dapat dilihat saja, tidak mengandung unsur suara (Sundayana, 2013). Menurut Hamalik (1994), fungsi media gambar yaitu edukatif, sosial, ekonomis, politis, seni dan budaya. Selain itu, gambar juga dapat menimbulkan daya tarik pada diri siswa, mempermudah pengertian dan memperjelas bagian-bagian yang penting yang akan ditulis.

Pembelajaran TTW yang dikombinasikan dengan media gambar ini diharapkan dapat membantu siswa untuk lebih memahami materi matematika yang dipelajari dan pada akhirnya berdampak kepada meningkatnya hasil belajar yang diperoleh siswa.

\section{METODE PENELITIAN}

Penelitian ini merupakan Penelitian Tindakan Kelas (PTK) yang dilaksanakan di SD Negeri 1 Purwosari Kecamatan Natar pada siswa kelas VI Tahun Ajaran 2014/2015. Subjek penelitian ini adalah siswa kelas VI yang berjumlah 38 orang. Pada penelitiaan ini menggunakan model yang dikemukakan Kemmis dan Mc Taggart (Arikunto, 2013) yang terdiri dari empat tahap yaitu: (1) perencanaan; pelaksanaan; (3) pengamatan; dan (4) refleksi. Pada empat tahap tersebut, dalam penelitian ini dilakukan secara bersiklus. Masing-masing siklus terdiri dari empat pertemuan dan dilanjutkan dengan tes untuk mengetahui hasil belajar siswa.

Teknik pengumpulan data dalam penelitian ini adalah dengan teknik tes. Instrumen yang digunakan adalah dengan lembar soal yang digunakan untuk mengetahui hasil belajar siswa yang dibatasi hanya pada ranah kognitif. Teknik analisis data menggunakan statistik deskriptif 
untuk data kuantitatif berupa hasil belajar siswa, dan didukung dengan data kualitatif untuk melengkapi gambaran yang diperoleh dari data kuantitatif.

\section{HASIL PENELITIAN DAN PEMBAHASAN}

Pada penelitian ini dilakukan sebanyak dua siklus dan setiap siklus terdiri dari empat kali pertemuan. Pada setiap pertemuan dilakukan selama $2 \times 35$ menit. Setelah dilakukan pembelajaran sebanyak empat pertemuan,

Tabel 1 Rekapitulasi Nilai Siklus 1

\begin{tabular}{|c|c|c|c|}
\hline No & Nilai & frekuensi & Presentase \\
\hline 1 & $40-49$ & 8 & $21,05 \%$ \\
\hline 2 & $50-59$ & 16 & $42,10 \%$ \\
\hline 3 & $60-69$ & 8 & $21,05 \%$ \\
\hline 4 & $70-79$ & 6 & $15,80 \%$ \\
\hline 5 & $80-89$ & 0 & $0 \%$ \\
\hline \multicolumn{2}{|c|}{ Jumlah } & $\mathbf{3 8}$ & $\mathbf{1 0 0 \%}$ \\
\hline
\end{tabular}

Pada siklus 1, dilakukan pembelajaran sesuai dengan langkah-langkah pembelajaran TTW dengan diawali penyampaian materi dari guru dengan menggunakan media gambar. Hal ini bertujuan untuk lebih memudahkan siswa dalam memahami isi materi. Materi pada siklus 1 adalah geometri yang berkaitan dengan bangun datar. Setelah itu, dimulai langkah Think dimana siswa diberikan permasalahan untuk dikerjakan secara individu terlebih dahulu. Pada tahap ini, masih banyak siswa yang masih bingung dalam menyelesaikan masalah, dan dilakukan tes pada masing-masing siklus.

\section{Siklus 1}

Dari 38 siswa yang mengikuti pembelajaran TTW berbantuan media gambar diketahui bahwa nilai tertinggi yang diperoleh siswa adalah 76 dan nilai terendah yang diperoleh adalah 42. Rata-rata perolehan nilai hasil belajar pada siklus $1 \mathrm{ini}$ adalah 56,3. Data rekapitulasi nilai siswa pada siklus 1 ini dapat dilihat pada tabel 1 . 
diskusi sesuai dengan langkah TTW. Siswa juga masih kesulitan untuk berpikir secara individu pada saat tahap Think. Beberapa siswa masih belum terlihat percaya diri dalam menyelesaikan masalah secara individu. Selanjutnya adalah sistem kelompok diskusi belum berjalan dengan baik, hal ini dapat dikarenakan anggota kelompok diskusi pembagiannya belum teratur, artinya pada beberapa kelompok masih ada yang beranggotakan siswa yang berada dalam ketegori kurang.

Untuk mengatasi beberapa permasalahan di siklus 1, maka dilakukan rencana penyelesaian masalah yang ditemukan pada siklus 1. Pada siklus 2, dibuat lembar kerja siswa (LKS) yang diberikan untuk masing-masing siswa agar pembelajaran lebih terlihat aktif. Selanjutnya untuk pembagian kelompok dilakukan dengan pengelompokkan berdasarkan nilai atau kemampuan siswa, jadi siswa yang memiliki kemampuan baik juga dikelompokkan dengan siswa yang memiliki kemampuan kurang.

\section{Siklus 2}

Pada siklus 2 ini, dari 38 siswa diperoleh nilai tertinggi adalah 82 dan nilai terendah yang diperoleh adalah 52. Selanjutnya rata-rata perolehan nilai hasil belajar pada siklus 2 ini adalah 72,10 . Data rekapitulasi nilai siswa pada siklus 2 ini dapat dilihat pada tabel 2 .

Tabel 2 Rekapitulasi Nilai Siklus 2

\begin{tabular}{|c|c|c|c|}
\hline No & Nilai & frekuensi & Presentase \\
\hline 1 & $40-49$ & 0 & $0 \%$ \\
\hline 2 & $50-59$ & 6 & $15,78 \%$ \\
\hline 3 & $60-69$ & 3 & $7,89 \%$ \\
\hline 4 & $70-79$ & 17 & $44,73 \%$ \\
\hline 5 & $80-89$ & 12 & $31,60 \%$ \\
\hline \multicolumn{2}{|c|}{ Jumlah } & $\mathbf{3 8}$ & $\mathbf{1 0 0 \%}$ \\
\hline
\end{tabular}

Pada siklus 2, kembali dilakukan pembelajaran sesuai dengan langkah - langkah pembelajaran TTW dengan diawali penjelasan menggunakan media gambar. Materi pada siklus 2 melanjutkan dari materi siklus 1 hanya saja masih berkaitan dengan geometri bidang datar.
Pada siklus 2, siswa cenderung lebih bertambah aktif dalam proses pembelajaran. Siswa diberikan sedikit pemberian materi dengan memanfaatkan media gambar kemudian diberikan lembar kerja siswa untuk dikerjakan secara mandiri, baru kemudian dibentuk kelompok yang sesuai dengan arahan guru. 
Adanya pengelompokan yang direncanakan sebelumnya, membuat sebagian siswa lebih mudah memahami materi karena beberapa siswa dibantu dengan teman kelompoknya yang cenderung lebih memahami materi.

Berdasarkan data yang diperoleh dari siklus 1 dan 2 , maka perbandingannya dapat dilihat pada Tabel 3.

Tabel 3 Perbandingan Nilai Siklus 1 dan Siklus 2

\begin{tabular}{|c|c|c|c|}
\hline No & Uraian & Siklus 1 & Siklus 2 \\
\hline 1 & Nilai $40-49$ & 8 & 0 \\
\hline 2 & Nilai $50-59$ & 16 & 6 \\
\hline 3 & Nilai $60-69$ & 8 & 3 \\
\hline 4 & Nilai $70-79$ & 6 & 17 \\
\hline 5 & Nilai $80-89$ & 0 & 12 \\
\hline 6 & Rata-Rata & 56,30 & 76,10 \\
\hline 7 & Tuntas KKM & 14 & 32 \\
\hline 8 & Tidak Tuntas KKM & 24 & 6 \\
\hline
\end{tabular}

\section{Pembahasan}

Secara keseluruhan kegiatan yang telah dilakukan dari siklus 1 sampai dengan siklus 2, maka hasil belajar siswa mengalami peningkatan. Pembelajaran Think Talk Write (TTW) dapat berjalan dengan baik, meskipun ketika di awal pertemuan, siswa masih belum bisa mengikuti pembelajaran dengan maksimal. Pembagian kelompok pada pembelajaran TTW dimulai dengan pembentukan kelompok oleh siswa, jadi siswa membentuk kelompok sendiri. Hal ini sebenarnya cukup baik, karena siswa akan lebih mengenal teman kelompoknya.

Namun kenyataannya, terdapat beberapa kelompok yang tidak bisa berjalan dengan baik dikarenakan anggota kelompoknya sama - sama memiliki kemampuan yang kurang baik dalam matematika.

Pengelompokan pada siklus

2 dilakukan pembagian dengan cara berbeda dari siklus 1. Guru terlebih dahulu membagi kelompok disesuaikan dengan kemampuan siswa, artinya dalam kelompok terdiri dari siswa yang berkemampuan heterogen. Selanjutnya dalam kegiatan pembelajaran TTW, guru lebih mengarahkan siswa agar dapat menuliskan penyelesaian masalah secara individu walaupun sekedar apa yang diketahui dan ditanyakan. Pembagian waktu dalam kegiatan TTW juga lebih ditegaskan lagi kepada siswa.

Selain dari kegiatan pembelajaran yang berkelompok, penggunaan media gambar juga cukup membantu siswa dalam memahami materi yang diberikan, 
terlebih lagi meteri tersebut merupakan materi geometri yang memerlukan visualisasi yang baik. Media gambar ini digunakan karena pada SD Negeri 1 Purwosari belum memiliki fasilitas komputer atau ICT yang cukup. Siswa dalam proses pembelajaran ikut serta dalam memanfaatkan media gambar tersebut. Berbagai gambar bangun datar yang ditunjukkan membantu siswa untuk lebih memahami materi bangun datar.

Berdasarkan pemaparan tersebut, secara keseluruhan pembelajaran TTW dengan berbantuan media gambar dapat meningkatkan hasil belajar siswa. Hal ini menunjukkan bahwa pembelajaran tersebut cukup berhasil dan cukup baik untuk digunakan dalam memperbaiki hasil belajar siswa khususnya dalam pelajaran matematika.

\section{KESIMPULAN DAN SARAN}

Berdasarkan hasil penelitian dan pembahasan yang telah dijelaskan, maka dapat disimpulkan bahwa pembelajaran Think Talk Write (TTW) berbantuan media gambar dapat meningkatkan hasil belajar siswa khususnya pada ranah kognitif yang diketahui dari perolehan nilai siswa setelah mengikuti tes di siklus 1 dan siklus 2 .

Saran yang dapat diberikan berdasarkan penelitian ini adalah dalam penggunaan pembelajaran
TTW, pembentukan kelompok sebaiknya dibuat secara heterogen dan lebih memperhatikan lagi alokasi waktu supaya tidak membuang banyak waktu di salah satu tahap TTW. Selain itu dalam pembelajaran untuk SD sebaiknya menggunakan media atau alat peraga sesuai dengan materi yang akan dipelajari untuk lebih membantu pemahaman siswa.

\section{DAFTAR PUSTAKA}

Arikunto, S. 2013. Prosedur Penelitian Suatu Pendekatan Praktik. Jakarta: Rineka Cipta.

Sundayana, R. 2013. Media dan Alat Peraga dalam Pembelajaran Matematika. Bandung: Alfabeta.

Hamalik, O. 1994. Media Pendidikan. Bandung: Cipta Adiya Bakti.

Sanjaya, W. 2006. Strategi Pembelajaran Berorientasi Standar Proses Pendidikan. Jakarta: Kencana.

Rochmad. 2013. Keterampilan Berpikir Kritis Dan Kreatif Dalam Pembelajaran Matematika. Makalah. Seminar Nasional Matematika di Universitas Negeri Semarang. Semarang, 26 Oktober.

Yamin, M., dan Ansari, B., I. 2012. Taktik Mengembangkan Kemampuan Individual Siswa. Jakarta: Gaung Persada. 